\begin{tabular}{|c|c|c|c|c|c|}
\hline MUNIBE Antropologia-Arkeologia & $n^{\circ} 71$ & $129-136$ & DONOSTIA & 2020 & ISSN 1132-2217 • elSSN 2172-4555 \\
\hline
\end{tabular}

\title{
Ankle lesions and shortening of the forearm on a female from the Roman city of Augusta Emerita (Mérida, Spain): consequences of an accidental traumatic episode during growth?
}

\author{
Lesiones en el tobillo y antebrazo de una mujer de la ciudad romana \\ de Augusta Emerita (Mérida, España): ¿consecuencias de un episodio \\ accidental traumático durante su crecimiento?
}

KEY WORDS: Colles fracture; Weber B fracture; antemortem; bone shortening; heterotopic ossification.

PALABRAS CLAVES: Fractura Colles; fractura Weber tipo B; ante mortem; encortamiento óseo; osificación heterotópica.

GAKO-HITZAK: Colles haustura; Weber B haustura; ante mortem; hezurren laburtzea; osifikazio heterotopikoa.

Filipa CORTESÃo SILVA ${ }^{(1) *}$, Juana MÁRQUEZ PÉREZ ${ }^{(2)}$

\section{ABSTRACT}

In one Roman funerary area ( $1^{\text {st }}-2^{\text {nd }}$ centuries AD) of Augusta Emerita, an adult female skeleton was found, showing multiple healed trauma, being one the first evidences of this kind documented in the capital of Lusitania. This study describes those lesions, reconstructs the possible events responsible and hypothetical impact on the subject's quality of life.

Macroscopic and radiological observation revealed fractures of the left distal third of the radius and the ulnar styloid process, as well as of the distal third of the left fibula. Those of the forearm, caused a shortening of about one centimetre, probably resulting from a fall during growth. The fracture of the fibula would have occurred from an underfoot accident resulting also in a heterotopic ossification of the distal anterior ligament. Since both fractures are well consolidated and without degenerative articular lesions, this woman probably did not suffer significant sequelae thereafter.

\section{RESUMEN}

En un área funeraria romana (siglos I-II d.C.) de Augusta Emerita fue descubierto el esqueleto de una mujer adulta mostrando un trauma múltiple cicatrizado, siendo una de las primeras evidencias de este tipo documentadas en la capital de la provincia Lusitania. Este estudio describe las lesiones, reconstruye los posibles eventos responsables y su hipotético impacto en la calidad de vida del individuo. Las observaciones macroscópicas y radiológicas revelan fracturas del tercio distal del radio y del proceso estiloide del cúbito izquierdos, así como del tercio distal del peroné izquierdo. Las del antebrazo ocasionaron un acortamiento de cerca de un centímetro, fruto posiblemente de una caída durante su desarrollo. La fractura de peroné habrá sido consecuencia de un accidente del pie que provocó, además, una osificación heterotópica del ligamento anterior distal. Dado que las fracturas se presentan bien consolidadas y sin lesiones articulares degenerativas, esta mujer probablemente no tuvo secuelas significativas.

\section{LABURPENA}

Augusta Emeritako hilobi-gune erromatar batean (K.o. I-II. mendeak) orbaindutako politraumatismoa zuen emakume heldu baten eskeletoa aurkitu zuten, eta era honetako lehenengo ebidentzietako bat da Lusitania probintziako hiriburuan. Ikerketa honek lesioak deskribatzen ditu, eta horiek eragile izan zitezkeen gertakariak eta emakumearen bizi-kalitatean eragin zezaketen inpaktua berreraikitzen ditu. Behaketa makroskopikoek eta erradiologikoek erakusten dute hausturak zituela erradioaren heren distalean, ezkerreko kubituaren estiloide apofisian, eta ezkerreko peronearen heren distalean. Besaurreko hausturek besaurrea bera zentimetro bat laburragoa izatea eragin zuten, ziurrenik emakume horrek garatzen ari zen bitartean erorikoren bat eduki izanaren ondorioz. Peronearen haustura oineko istripu baten ondorioz gertatuko zen, zeinak, horretaz gain, aurreko lotailu distalaren osifikazio heterotopikoa ere eragin baitzuen. Badirudi hausturak ondo kontsolidatuta zeudela eta ez dutela artikulazioetako lesio degeneratiborik eragin eta, beraz, emakumeak ez zuen ondorio esanguratsurik izango.

\footnotetext{
(1) Research Centre for Anthropology and Health (CIAS), Department of Life Sciences, University of Coimbra, Calçada Martim de Freitas, Edifício de São Bento, 3000-456 Coimbra, Portugal; filipa.cortesao@gmail.com.

(2) Consorcio Ciudad Monumental de Mérida, C/ Santa Julia, n’ 5, 06800, Mérida, Badajoz, Spain; juana@consorciomerida.org

${ }^{*}$ Corresponding author
} 


\section{INTRODUCTION}

The city of Augusta Emerita (nowadays Mérida, Spain) was a colony founded by Augustus in the year 25 BC. It became the capital of the Roman province of $L u$ sitania (Arce, 2004) (Figure 1). Thanks to the numerous archaeological excavations carried out over more than a century, several civic structures have been discovered, including the Theatre and Amphitheatre, the Circus, as well as funerary buildings, such as the famous "Columbarios" (Álvarez y Mateos, 2010).

As with other Roman cities, the funerary areas identified are located outside the walls and near the main roads: they have presented cremation burials and inhumations, in different proportions depending on the historical period (Márquez, 2008; Murciano, 2010). South of the city, one funerary location (archaeological intervention number 5038), dating from High Empire ( $1^{\text {st }}$ to $2^{\text {nd }}$ centuries AD), revealed a skeleton of an adult female with multiple traumatic lesions, whose nature and the reconstruction of the possible associated events, as well as its impact on her living conditions, are the subject of this article.

\section{MATERIAL AND METHODS}

The archaeological intervention number 5038 was conducted in 2005 under the supervision of Juana Már- quez Pérez, archaeologist of the Consorcio Ciudad Monumental de Mérida. It took place at González Serrano Street, in a zone currently known as "Los Bodegones". The excavated area, covering $474.37 \mathrm{~m}^{2}$, revealed 32 cremation graves and two inhumations, dating from the $1^{\text {st }}$ to the $2^{\text {nd }}$ centuries AD (Márquez, 2005). Other archaeological investigations made in neighbouring plots yielded other burials of the same sorts, indicating that they are all temporally and spatially related (Márquez, 2005; see Silva, 2015; 2018).

One of the inhumations excavated contained the individual of the present study (5038/A2/UE47). Deposited in a rectangular double pit, she was laid supine in a west-east orientation (Márquez, 2005). Part of the skeleton, namely the ribs, spine, hip bones, hands and femurs, were not anatomically articulated, indicating that they had been subject to a taphonomic process of indeterminate nature that had disordered them (Figure 2). This burial did not show vestiges of any covering nor grave goods (Márquez, 2005).

Concerning the anthropological analysis, it is based on the recommendations of Buikstra y Ubelaker (1994). In addition, Ferembach et al. (1980), Brooks y Suchey (1990) and Lovejoy et al. (1985) were consulted for the estimation of age at death, as well as Ferembach et al. (1980) and Wasterlain (2000) for sexual diagnosis. The left humerus, femur and tibia, plus the bones of both

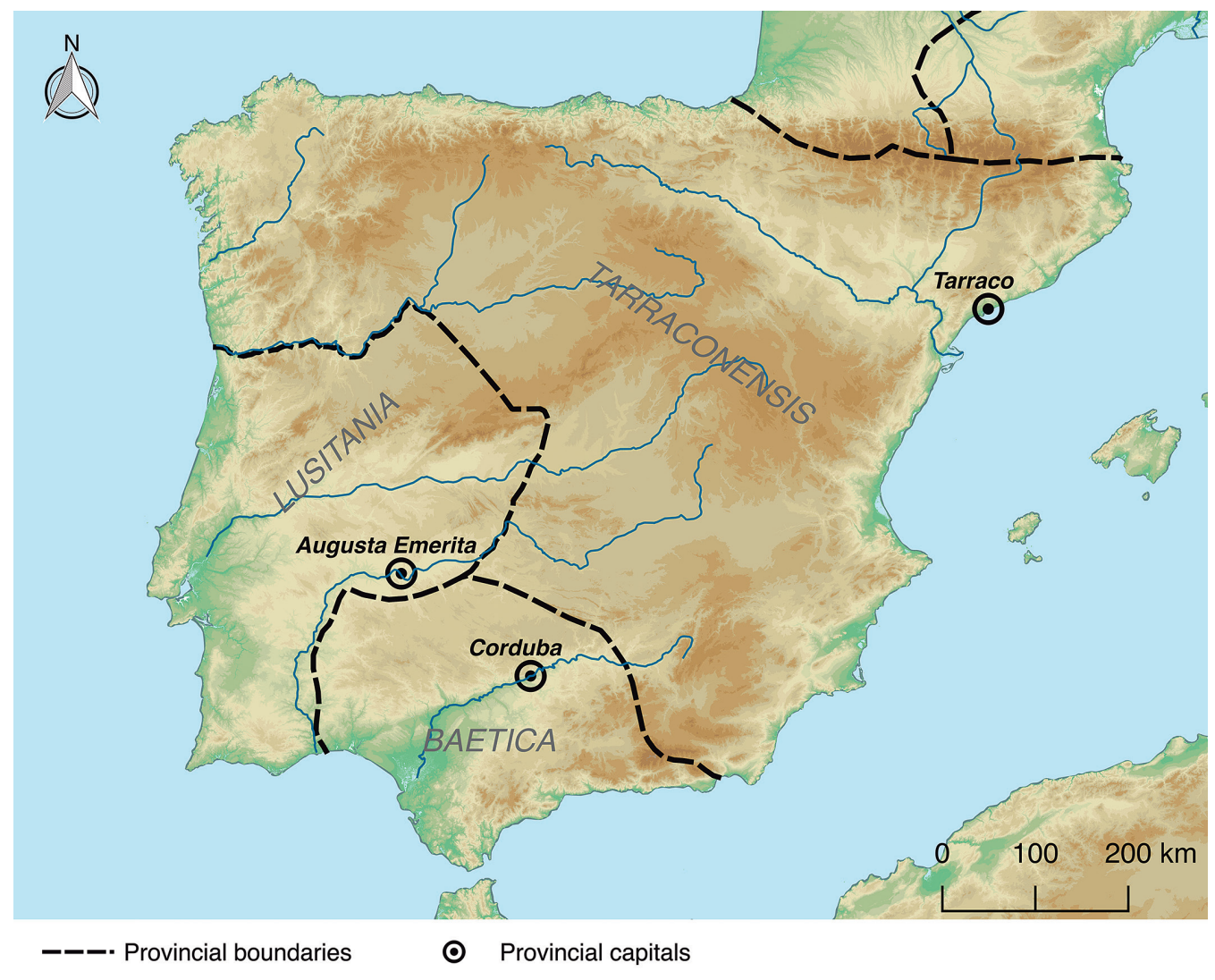

Fig.1. Location of Augusta Emerita in Lusitania, one of the three Hispanic Roman provinces during the High Empire. Map by Maria José de Almeida. / Localización de Augusta Emerita en Lusitania, una de las tres provincias de la Hispania romana durante el Alto Imperio. Mapa de Maria José de Almeida. 


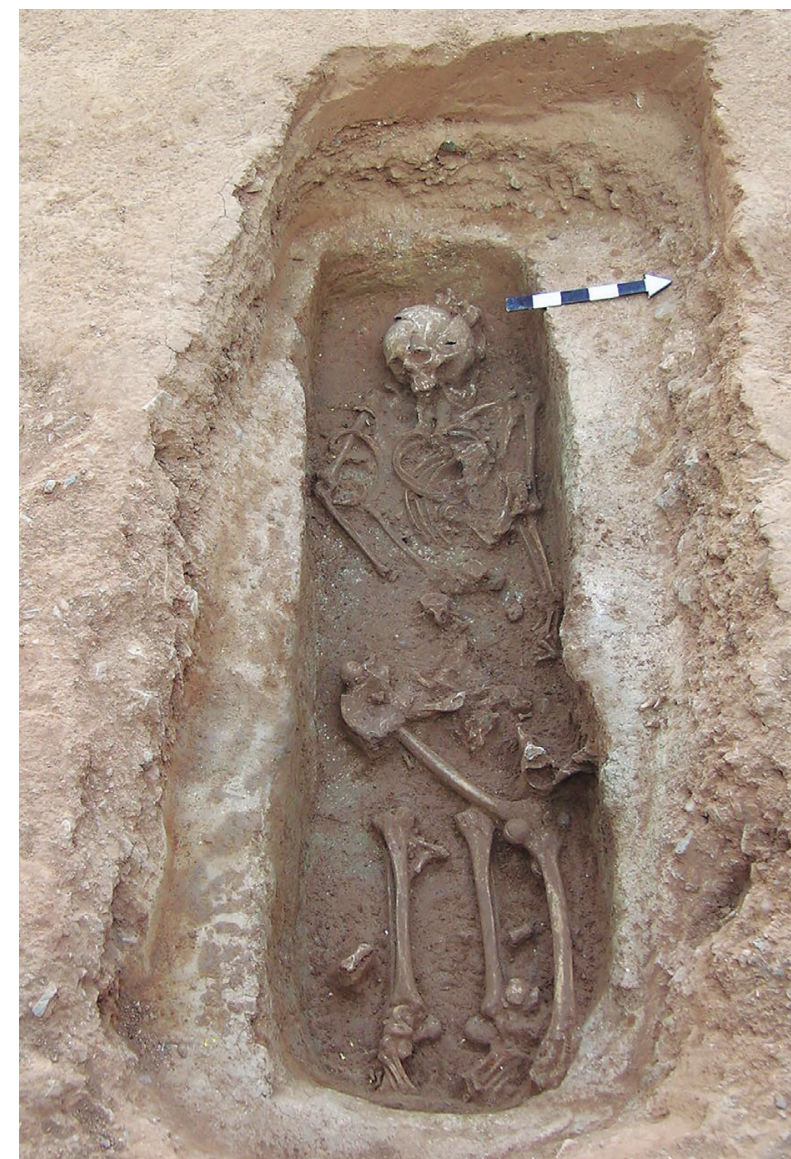

Fig.2. Burial with the skeletal remains of the individual studied (5038/A2) UE47). / Sepultura con los restos óseos del individuo estudiado (5038/ A2/UE47).

forearms were measured (Buikstra y Ubelaker, 1994) using an osteometric tab, a tape measure and a digital caliper (Mitutoyo, $0.01 \mathrm{~mm}$ precision). Moreover, the left and right radius and ulna, as well as the left tibia and fibula were photographed and radiographed (GE Healthcare, Senographe DC, reference 5131764-7-1PT). The theoretical foundation for the analysis and description of traumatic injuries came mainly from the works of Judd y Redfern (2012), Lovell (1997), Ortner (2003) and Waldron (2009), while the classification of fractures detec- ted in the forearm and ankle conform to the proposals of Frykman (1967) and Weber (1972), respectively.

\section{RESULTS}

Age-at-death estimation and sex determination indicate a mature adult female (30-49 years). Moreover, the macroscopic and radiological observation of the lesions revealed several antemortem fractures on the left upper and lower limbs, namely, on the forearm and ankle. For the first, a well-consolidated oblique fracture in the distal third of the radial diaphysis (Colles fracture) (Figure 3) and a crush fracture in the ulnar styloid process (Figure 4) were identified, which correspond to type II, according to Frykman's (1967) classification of distal radial fractures. In addition, both radius and ulna present a shortening of about one centimetre relative to the other arm (Figure 5, Table I). If we consider the ca-

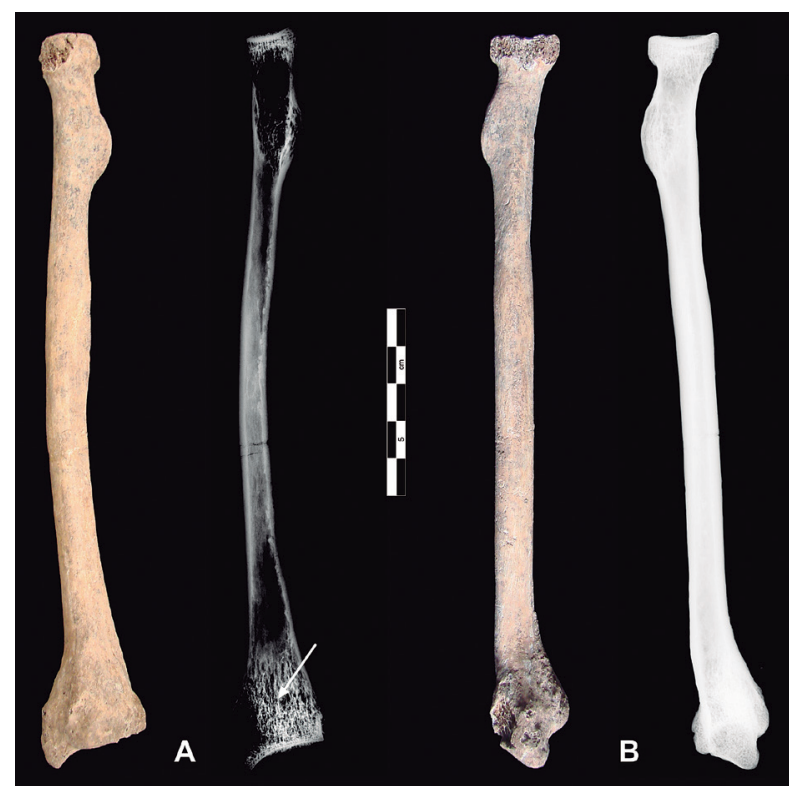

Fig.3. Colles fracture on the distal end of the left radius. A) posterior view (where an oblique fracture can be seen on the radiograph). B) lateral view. / Fractura de Colles en el extremo distal del radio izquierdo. A) norma posterior (donde puede observarse una fractura oblicua en la radiografía). B) norma lateral.

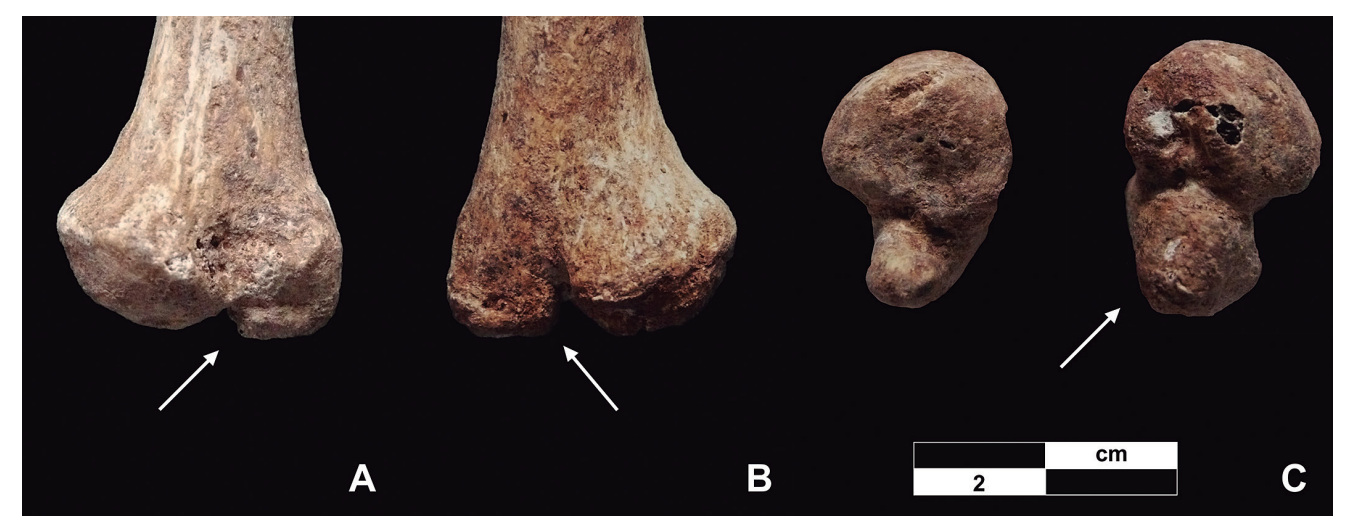

Fig.4. Crush fracture in the left ulnar styloid process. Views: A) lateral, B) medial, C) inferior, with right ulna for comparison. / Fractura por aplastamiento en la apófisis estiloides cubital izquierda. Normas: A) lateral, B) medial, C) inferior, con cúbito derecho para comparación. 


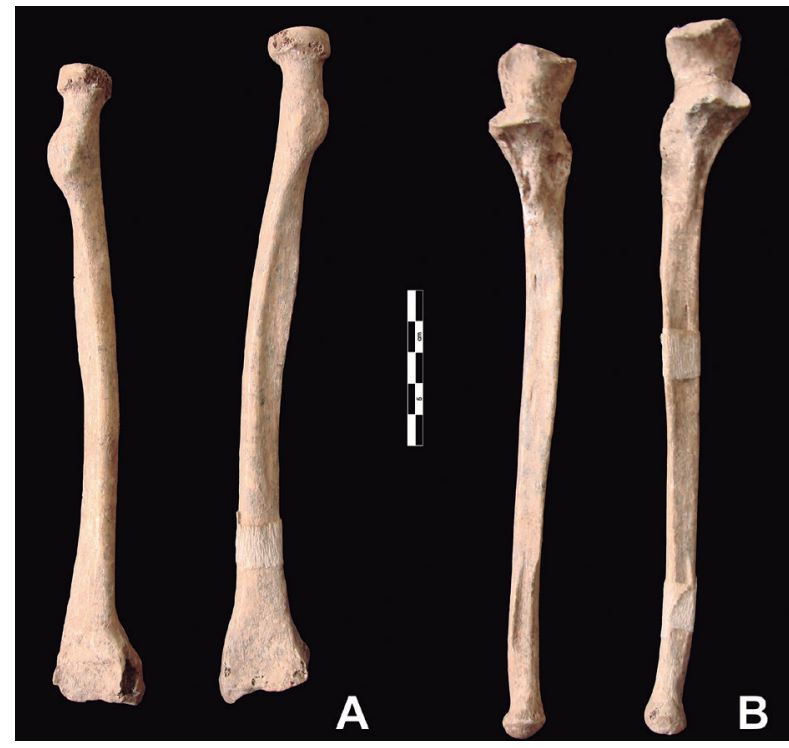

Fig.5. Shortening of the left radius and ulna in relation to those of the right arm. Anterior view. / Acortamiento del radio y cúbito izquierdos en relación a sus simétricos. Norma anterior.

\begin{tabular}{|l|c|c|c|}
\hline \multicolumn{4}{|c|}{ Maximum length $(\mathbf{c m})$} \\
\hline Bone & LEFT & RIGHT & DIFFERENCE \\
\hline Radius & 19.3 & 20.4 & 1.1 \\
\hline Ulna & 21.8 & 22.6 & 0.8 \\
\hline
\end{tabular}

Table 1: Maximum length $(\mathrm{cm})$ of the bones of the left and right forearms, according to Buikstra y Ubelaker (1994). / Longitud maxima (cm) de los huesos del antebrazo izquierdo y derecho, según Buikstra y Ubelaker (1994).

tegorization proposed by Paley for the discrepancies in the length of the forearm, those values place it in type $\mathrm{V}$ (in Paley y Kelley, 2000). No signs of joint degenerative lesions were observed.

Regarding the lower limbs, an oblique fracture of the distal third of the fibula was observed (Figure 6),

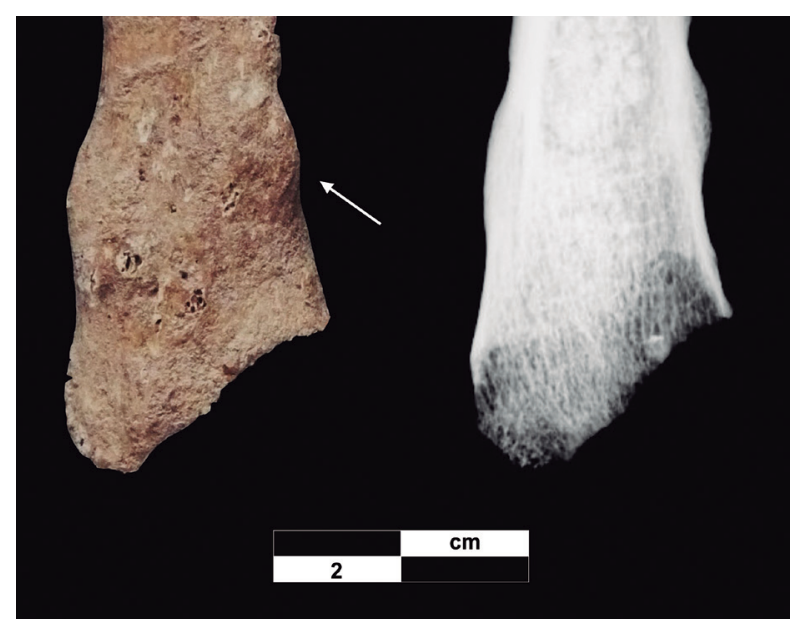

Fig.6. Distal third of the left fibula showing a callus due to an oblique fracture. Medial view. / Tercio distal del peroné izquierdo con callo óseo fruto de fractura oblicua. Norma medial. that is, a type B ankle fracture according to Weber's (1972) classification. It was well consolidated and without associated deformation. In the distal third of tibia a heterotopic ossification of the syndesmosis was also recorded (Figure 7 ). In the lower limbs no degenerative lesions were noted.

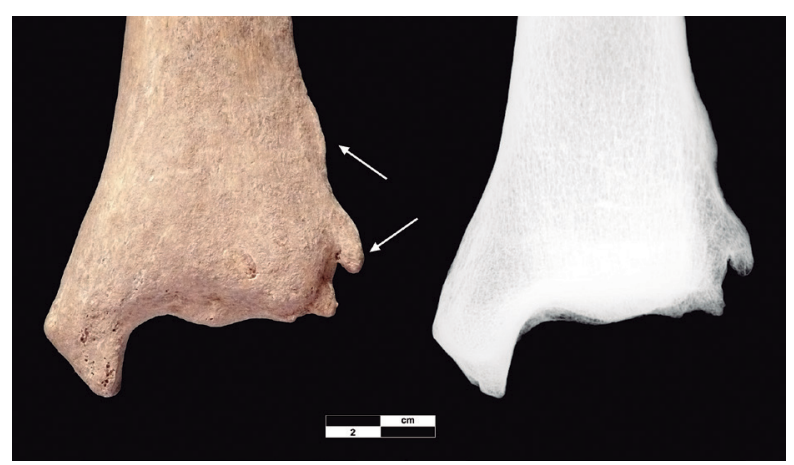

Fig.7. Left tibia presenting heterotopic ossification of the distal tibio-fibular syndesmosis. Anterior view. / Tibia izquierda con osificación heterotópica de la sindesmosis tibioperonea distal. Norma anterior.

\section{DISCUSSION}

The forearm fractures are one of the most common traumatic lesions in past and present populations (e.g. Gilmour et al., 2015; Waldron, 2009), particularly that of the distal third of the radius. The latter, in modern clinical practice, accounts for $20 \%$ to $30 \%$ of fractures in the pediatric group (e.g. Cooper et al., 2004; Landin, 1983; Nellans et al., 2012; Pretell-Mazzini y Rodriguez-Martin, 2010) and near to $18 \%$ in the elderly group, affecting mainly women (Alffram y Bauer, 1962).

At the clinical level, it is noted that distal radius fractures are often accompanied by fractures in the ulnar styloid process (Mulders et al., 2018). Such evidence is also occasionally documented in skeletons of both sexes in archaeological contexts. From Roman times, several cases were found in Ossonoba, Faro, Portugal (Fernandes, 2012), Aquincum, Budapest, Hungary (Gilmour et al., 2015), Ancester, England (Gilmour, 2017) and north of the Fosse Way, Cirencester, England (Wells, 1982).

Regarding the Colles fracture, most cases reported in palaeopathological literature, namely those from Roman sites, are not associated to a ulna styloid fracture and affect adults of both sexes (e.g. Bonsall, 2013; Gilmour, 2017; Gilmour et al., 2015; Graham, 2016; Mays, 2006; Polo, 2016; Redfern, 2010; Wells, 1982).

Bone shortening represents one of the possible consequences of a fracture due to factors such as overlap, substantial angulation, crushing or gross bone loss (Lovell, 1997). Another circumstance leading to bone shortening can occur when fractures located in or near the epiphyses happen during growth, as a result of a lesion on the growth plate leading to a premature fusion of 
the affected bone (Lewis, 2017; Ortner, 2003; Peterson, 2007; Redfern y Roberts, 2019). This seems to be the case since radius and ulna similar shortening are linked to well-consolidated fractures.

In the palaeopathological record, evidence of bone shortening due to fractures occurring during growth are scarce. However, at least three cases dated from medieval and post-medieval period were identified in England, involving juveniles aged between 10 and 17 years (e.g. Lewis, 1999; Ortner, 2003). In two of them, the affected bones were the tibia, while for the third it was the humerus and clavicle (e.g. Lewis, 1999; Ortner, 2003).

Generally, the amount of bone shortening depends on several factors, such as: the individual's age at the time of trauma, the affected epiphysis, and the amount of missing longitudinal growth (Lewis, 2017; Peterson, 2007). Knowing that the distal radius and ulna plate accounts for $75 \%$ and $81 \%$ of bone longitudinal growth, respectively (Digby, 1915 in Noonan y Price, 1998) and that that distal ulna growth in seven-year-old girls up until the maturing of the skeleton runs at $0.9 \mathrm{~cm}$ per year before ceasing at 15 years (Pritchett, 1993 in Peterson, 2007), we calculate that, in the present case, the fracture may have occurred in adolescence, around 12 to 13 years, since the left ulna shows a shortening of about 1 $\mathrm{cm}$ in relation to its pair.

The estimated age at which those fractures happened coincides with the peak of incidence reported in clinical studies, namely at the onset of puberty, between 10 and 14 years of age (Alffram y Bauer, 1962). Girls and boys present, however, different age peaks (Handoll et al., 2016; Nellans et al., 2012). According to Bailey et al. (1989), those values cluster at 11.5 to 12.5 years for girls and 13.5 to 14.5 years for boys.

Considering the characteristics of the forearm lesions presented by the woman of Augusta Emerita, i.e. the type of fracture, its state of remodelling, and the analogous bone shortening of radius and ulna this appears the most plausible hypothesis, but we must keep in mind that bone shortening associated to fractures made during adulthood is another possible scenario, which had been documented at clinical and archaeological contexts (e.g.; Mays, 2006; Perinha et al., 2018). The application of paleohistological techniques could help to assess the post-traumatic interval, although this is invasive technique (Assis y Keenleyside, 2016; De Boer et al., 2015).

In the scientific community, the Colles fracture is seen as the result of indirect trauma (Lovell, 1997), specifically, a fall with the hand outstretched (Ortner, 2003; Redfern y Roberts, 2019; Waldron, 2009). The radial and ulnar fractures of the emeritensis woman suggest that they are the result of a single traumatic episode of an accidental nature, namely a fall.

Regarding the lower limb lesions, it is important to mention that the fibula is one of the bones most affected by fractures in adults, as seen in present and past po- pulations (e.g. Waldron, 2009). Furthermore, one of the sites particularly susceptible to injury corresponds to the distal third of this bone, although the equivalent segment of the tibia and the syndesmosis may also be involved, as is shown by clinical and anthropological studies (e.g. Gilmour et al., 2017; Van Heest y Lafferty, 2014).

In ancient populations, the oblique distal fracture of the fibula is a common occurrence, being identified, for example, in individuals from several Roman provinces (e.g. Bonsall, 2013; Gilmour, 2017; Gilmour et al., 2015; Redfern, 2010). Less usual is the presence of a heterotopic ossification of the syndesmosis, although sometimes such are reported in osteoarchaeological analyses (e.g. Bonsall, 2013, Gilmour, 2017), as well as in modern medical literature (e.g. Kellett, 2011; Robles et al., 2015; Van Heest y Lafferty, 2014). According to diverse clinical studies, the overall incidence of syndesmotic lesions in ankle fractures range between 0.5 to $66 \%$ (Plessis et al., 2008). Nevertheless, the distal tibio-fibular synostosis only occurs in 6 to $12 \%$ of the cases (Albers et al., 1996).

In the woman from Augusta Emerita, the distal fracture of the fibula probably will have resulted from the rupture of the anterior inferior tibio-fibular ligament, one of the four ligaments of the distal tibio-fibular syndesmosis (see Hermans et al., 2010; Van Heest y Lafferty, 2014). This syndesmosis lesion gave rise to the formation of a hematoma that probably calcified, so producing a heterotopic ossification (Ozkan Kose, personal communication; e.g. Robles et al., 2015), yet without tibio-fibular synostosis. The type of fracture suggests that it may have been a consequence of an abrupt movement of the foot, probably of an external supination-rotation of the ankle joint (e.g. Gougoulias et al., 2010; Van Heest y Lafferty, 2014). This constitutes one of the so-called "underfoot accidents", which are more frequent in females (Davies et al., 2001, 2003). These accidents, associated with movement and loss of balance, also include other actions such as stumbling or slipping (Davies et al., 2001, 2003), culminating in falls like that mentioned above. However, given the available data, it is not possible to determine whether the ankle trauma occurred simultaneously with that of the forearm.

Functionally, we think that the forearm and ankle trauma did not have a significant impact on this woman's life. The fractures were well remodelled and without degenerative lesions, and even the complications suffered, namely the bone shortening of forearms and the ossification of tibiofibular syndesmosis would have not caused any great limitations, except, perhaps, a degree of pain, less strength in the grip and lower range of movements for the affected wrist (Gauger et al., 2017; Mulders et al., 2018), as well as pain and/or instability of the ankle ligaments (Golanó et al., 2010; Peña y Cetzee, 2006; Robles et al., 2015).

The similar shortening of the two forearm bones affected will have avoided, or minimized, the various 
problems connected with discrepantly sized radius and ulna, as noted in clinical studies (Gauger et al., 2017; Horii et al., 1993; Paley y Kelly, 2000). Despite the fact that the Colle fracture was associated with a fracture of the ulnar styloid process, this situation had no extra consequences in functional terms, although opinions do differ on this point (Mulders et al., 2018). In the ankle, the presence of heterotopic ossification of the inferior anterior tibio-fibular ligament may have caused some discomfort, however it will not have produced a severe functional problem, as happens when synostosis occurs (e.g. Robles et al., 2015).

As to the treatment of the fractures suffered by the woman, it is important to be aware that in Roman times there existed medical treatises, such as the famous De Medicina of Aulus Cornelius Celsus, written in the first half of the first century AD, whose volume VIII has a part dedicated to bones, with a series of deliberations about fractures and the procedures to adopt for their treatment (Richardson, 1979).

According to Celsus $(8,10,1)$, limb fractures were reduced and a temporary restraining device, made up of around six ligatures, preferably of linen, soaked in wine and oil was applied. Over the next days this device was periodically changed, and the fractures cleaned with hot water. After seven to nine days, the affected limb was again bandaged, but this time with splints to keep the bones in place (Celsus, 8, 10, 1), the so-called ferulae, in the case of the forearm (see Richardson, 1979). For the leg, a mould, named the canalis, whose size varied depending on the area involved, was used (see Richardson, 1979). These new devices would then remain in place for the time deemed necessary. Generally, a broken bone of the forearm or leg would take about 20 to 30 days to heal (Celsus, 8, 7,5).

A probable example of this type of practice was found with the bones of a seven to eight-years old child from the city of Herculanum (Herculanum \# 8), a victim of the Vesuvian eruption in the year 79 AD (Ottini et al., 2001). This child had evidence of treatment of fractures to its right forearm, a result of a possible fall occurring about four to five weeks before the eruption (Ottini et al., 2001). The excellent alignment of the fractured bones suggests that the two fragments of a shoot of vine wood found by the bones were traces of the ferulae used in the containment device (Ottini et al., 2001).

This occurrence is by no means unique. Antemortem fracture analysis of individuals from several Roman provinces also indicate that they may have been submitted to treatment, namely, realignment and immobilization (e.g. Gilmour et al., 2015; Redfern, 2010). Furthermore, other cases attest to surgical treatments, like trepanations and amputations (e.g. Redfern, 2010), corroborating remarks in historical sources and the finding of instruments used in these medical practices and also in the reduction of fractured bones (e.g. Bejarano, 2015; Cruse, 2004; Jackson, 1988).
In Mérida, there were found the graves of five medici associated with the provincial capital, four of them lived in $1^{\text {st }}$ to $2^{\text {nd }}$ centuries AD (Bejarano, 2015). Epigraphic data shows that those individuals were mostly general doctors, who practiced private medicine. Among the grave goods were objects of a medical and/or pharmaceutical nature (Bejarano, 2015).

Despite the undoubted existence of doctors in this Roman city, their presence has not been revealed in the bones of the inhabitants; there were no unequivocal signals of medical practices, as has happened in other Roman provinces. For the moment, only the case of a single child, aged about three years old, bears witness: it had survived for a month or two after a head trauma involving the frontal and zygomatic parts of the skull, thanks to the care, one assumes, given by a doctor (Silva et al., 2014).

\section{CONCLUSIONS}

The multiple antemortem trauma presented by the woman of Augusta Emerita could be the result of one or of more accidents. If it was a single traumatic episode, it could be hypothesized that the above-mentioned "underfoot accident", which caused the ankle injuries, led, likewise, to the fall with the extended hand suffered probably during adolescence, which occasioned the fractures of the forearm. But it is also plausible that the ankle injuries resulted from a separate traumatic episode occurring, perhaps, in adulthood. Given the available data, both possibilities remain open, as in other cases involving multiple trauma.

The fact that the fractures are relatively well consolidated and without degenerative articular lesions, despite the shortening of the forearm and the heterotopic ossification of the distal anterior ligament, leads us to suppose that this woman did not suffer significant after-effects in her life. In turn this suggests that care was exercised in the alignment and immobilization of the bones by doctors, whose presence is, moreover, attested in this city.

\section{ACKNOWLEDGMENTS}

Research Centre for Anthropology and Health; Fundação para a Ciência e a Tecnologia (SFRH/ BD/31943/2006); Consorcio de Mérida; Serviço de Imagiologia dos CHUC; Ana Luísa Santos; Ozkan Kose; Maria José de Almeida; Sandra Assis; Jesús Acero Pérez.

\section{REFERENCES}

Albers, G.H., de Kort, A.F., Middenorf, P.R., Van Dijk, C.N., 1996. Distal tibiofibular synostosis after ankle fracture. The Journal Bone Joint Surgery. British 78-B(2), 250-252.

Alffram, P.-A., Bauer, G.C.H., 1962. Epidemiology of fractures of the forearm: a biomechanical investigation of bone strength. The Journal Bone Joint Surgery. Am. 44-A (1), 105-114. https:// doi.org/ 10.2106/00004623-196244010-00009. 
Álvarez Martínez, J.M., Mateos Cruz, P., 2010. 100 años de Arqueología en Mérida. In: Álvarez Martínez, J.M., Mateos Cruz, P. (Eds.), Mérida. 2000 años de Historia, 100 años de Arqueología. Cien años de excavaciones arqueológicas en Mérida 1910-2010, 27-43. Consorcio de la Ciudad Monumental, Histórico-Artística y Arqueológica de Mérida, Mérida.

Arce, J., 2004. Introducción histórica. En: Dupré-Raventós, X. (Ed.), Mérida: Colonia Augusta Emerita, 7-13. L'Erma di Bretschneider, Roma.

Assis, S., Keenleyside, A., 2016. Bellow the callus surface: applying paleopathological techniques to understand the biology of bone healing in skeletonized human remains. Pathobiology 83, 177-195.

Bailey, D.A., Wedge, J.H., McCulloch, R.G., Martin, A.D., Bernhardson, S.C., Saskatchewan, S., 1989. Epidemiology of fractures of the distal end of the radius in children as associated with growth. The Journal Bone Joint Surgery. Am. 71-A (8), 1225-1231.

Bejarano Osorio, A.M., 2015. La medicina en la Colonia Augusta Emerita. Serie Ataecina 9. Asamblea de Extremadura, Mérida.

Bonsall, L.A., 2013. Variations in the health status of urban populations in Roman Britain: a comparison of skeletal samples from major and minor towns. PhD Thesis. University of Edinburgh. Available from: https://www.era.lib.ed.ac.uk/handle/1842/8255.

Buikstra, J., Ubelaker, D., 1994. Standards for data collection from human skeletal remains: Proceedings of a seminar at the Field Museum of Natural History. Research Series 44. Arkansas Archaeological Survey, Fayetteville, AR.

Brooks, S., Suchey, J., 1990. Skeletal age determination based on the os pubis: a comparison of the Acsádi-Neméskeri and Suchey Brooks methods. Human Evolution 5(3), 227-238.

Celsus, Aul. Corn., 1831. De Medicina. A Translation of the Eight Books of Aul. Corn. Celsus on Medicine by G. F. Collier. Simpkin and Marshall, London. 2nd ed.

Cooper, C., Dennison, E.M., Leufkens, H.G.M., Bishop, N., Van Staa, T.P., 2004. Epidemiology of childhood fractures in Britain: a study using the general practice research database. Journal of Bone Mineral Research 19(12), 1976-1981.

Cruse, A., 2004. Roman Medicine. Tempus, Gloucestershire.

Davies, J.C., Manning, D.P., Kemp, G.J., Frostick, S.P., 2001. The rising number of underfoot accidents after the menopause causes both fractures and non-fractures injuries. QJM. 94(12), 699-707.

Davies, J.C., Kemp, G.J., Frostick, S.P., Stevens, G., Manning, D.P., 2003. Age and gender in underfoot accidents. Safety Science 41(1), 65-76.

De Boer, H., Van der Merwe, A.E., Steyn, M., Maat, G.J.R., 2015. Assessing post-traumatic time interval in human dry bone. International Journal Osteoarchaeology 25, 98-109.

Ferembach, D., Schwidetzky, I., Stloukal, M., 1980. Recommendations for age and sex diagnoses of skeletons. Journal of Human Evolution 9, 517-549.

Fernandes, H., 2012. Ossonoba Romana. Análise paleopatológica e paleobiológica de indivíduos adultos da amostra da necrópole do séc. I-III d.C. exumada do Largo 25 de Abril. Departamento de Ciências da Vida, Universidade de Coimbra. Available from: https://estudogeral.sib.uc.pt/handle/10316/21270.
Frykman, G., 1967. Fracture of the distal radius including sequelae-shoulder-hand-finger syndrome, disturbance in the distal radio-ulnar joint and impairment of nerve function: a clinical and experimental study. Acta Orthopaedica Scandinavica 108, 3-153.

Gauger, E.M., Casnovsky, L.L., Gauger, E.J., Bohn, D.C., Van Heest, A.E., 2017. Acquired upper extremity growth arrest. Orthopedics. 40 (1), e95-e103. https://doi.org/10.3928/0147744720160926-07

Gilmour, R.J., 2017. Resilient romans: cross-sectional evidence for long-term functional consequences of extremity trauma. PhD Thesis. McMaster University. https://macsphere.mcmaster.ca/handle/11375/21452.

Gilmour, R.J., Gowland, R., Roberts, C., Bernert, Z., Kiss, K.K., Lassányi, G., 2015. Gendered differences in accidental trauma to upper and lower limb bones at Aquincum, Roman Hungary. International Journal of Paleopathology 11, 75-91.

Golanó, P., Vega, J., de Leeuw, P.A.J., Malagelada, F., Manzanares, M.C., Götzens, V., Van Dijk, C.N., 2010. Anatomy of the ankle ligaments: a pictoral essay. Knee Surgery, Sports Traumatology, Arthroscopy 18, 557-569.

Gougoulias, N., Khanna, A., Sakellariou, A., Maffulli, N., 2010. Supination-external rotation ankle fractures: stability a key issue. Clinical Orthopaedics and Related Research 468, 243251. https://doi.org/10.1007/s11999-009-0988-2

Graham, I.A., 2016. Paleoepidemiological analysis of trauma in a Roman Period population from Kellis, Egypt, Circa 50-450 AD. Electronic Thesis and Dissertation Repository 4200. https://ir.lib.uwo.ca/etd/4200.

Handoll, H.H.G., Elliott, J., Iheozor-Ejiofor, Z., Hunter, J., Karantana, A., 2016. Interventions for treating wrist fractures in children (Protocol). Cochrane Database of Systematic Reviews, 12. Art. No.: CD012470. https://doi.org/10.1002/14651858. CD012470

Hermans, J.H., Beumer, A., de Jong, T.A., Kleinrensink, G.-J., 2010. Anatomy of the distal tibiofibular syndesmosis in adults: a pictorial essay with a multimodality approach. Journal of Anatomy 217, 633-645.

Horii, E., Tamura, Y., Nakamura, R., Miura, T., 1993. Premature closure of the distal radial physis. The Journal of Hand Surgery 18B (1), 11-16.

Jackson, R., 1988. Doctors and Diseases in the Roman Empire. British Museum Press, London.

Judd, M., Redfern, R., 2012. Trauma. In: Grauer, A.L. (Ed.), A Companion to Paleopathology, 359-379. Wiley Blackwell, Oxford.

Kellett, J.J., 2011. The clinical features of ankle syndesmosis injuries: a general review. Clinical Journal of Sport Medicine 21(6), 524-529. https://doi.org/10.1097/JSM.0b013e318234be7d

Landin, L.A., 1983. Fracture patterns in children. Analysis of 8,682 fractures with special reference to incidence, etiology and secular changes in a Swedish urban population 19501979. Acta Orthopaedica Scandinavica Suppl. 202, 3-109.

Lewis, M.E., 1999. The impact of urbanisation and industrialisation in medieval and post-medieval Britain: an assessment of the morbidity and mortality of non-adult skeleton from the cemeteries of two urban and two rural sites in England (AD 8501859). PhD Thesis, University of Bradford. Available from: https://bradscholars.brad.ac.uk/handle/10454/4196?show=full. 
Lewis, M., 2017. Paleopathology of children: identification of pathological conditions in the human skeletal remains of nonadults. Academic Press, London.

Lovejoy, C., Meindl, R., Pryzbeck, T., Mensforth, R., 1985. Chronological metamorphosis of the auricular surface of the ilium: a new method for the adult skeletal age at death. American Journal of Physical Anthropology 68, 15-28.

Lovell, N.C., 1997. Trauma analysis in Paleopathology. American Journal of Physical Anthropology 40, 139-170.

Márquez Pérez, J., 2005. Informe gráfico de los resultados de la intervención arqueológica en un solar sito en la c/ González Serrano s/n (12040/21-10S). Intervención arqueológica n`5038. Consorcio de la Ciudad Monumental de Mérida, Mérida. [Unpublished].

Márquez Pérez, J., 2008. Las áreas funerarias de Augusta Emerita entre los siglos I y III d. C. En: Mangas, J., Ángel Novillo, M. (Eds.), El territorio de las ciudades romanas, 443-476. Ediciones Sísifo, S.L., Madrid.

Mays, S.A., 2006. A paleopathological study of Colles' fracture. International Journal of Osteoarchaeology 16(5), 415-428.

Mulders, M.A.M., Snethlage, L.J.F., Keizer, R.-J.O.M., Goslings, J.C., Schep, N.W.L., 2018. Functional outcomes of distal radius fractures with and without ulnar styloid fractures: a metaanalysis. Journal of Hand Surgery (European volumen) 43(2), 150-157. https://doi.org/10.1177/1753193417730323.

Murciano Calles, J.M., 2010. Historiografía de los aspectos funerarios de Augusta Emerita (siglo I-IV). Cuadernos Emeritenses 36, 13-245. Museo Nacional de Arte Romano, Mérida.

Nellans, K.W., Kowalski, E., Chung, K.G., 2012. The epidemiology of distal radius fractures. Hand Clinics 28(2), 113-125.

Noonan, K.I., Price, C.T., 1998. Forearm and distal radius fractures in children. Journal of the American academy of Orthopaedic Surgeons 6, 146-156.

Ortner, D.J., 2003. Identification of pathological conditions in human skeletal remains, second ed. Academic Press, New York.

Ottini, L., Di Tota, G., Mariani-Costantini, R., Angeletti, L.R., La Verghetta, M., Capasso, L., Di Fabrizio, A., D’Anastasio, R., 2001. Evidence of a forearm fracture in a young victim of the AD 79 Vesuvius eruption. International Journal Paleopathology 13(3), 23-26.

Paley, D., Kelley, D., 2000. Lengthening and deformity correction in upper extremities. In: Raskin, K. (Ed.), Atlas of the Hand Clinics vol. 5, 117-172.

Peña, F.A., Cetzee, J.C., 2006. Ankle syndesmosis injuries. Foot and Ankle Clinics 11, 35-50.

Perinha, A., Nogueira, C., Umbelino, C., Silva, A.M., Cunha, E., Curate, F., 2018. Massa óssea cortical e fraturas de fragilidade na Coleção de Esqueletos Identificados do séc. XXI. Antropologia Portuguesa 35, 33-68.

Peterson, H.A., 2007. Epiphyseal growth plate fractures. Springer, Berlin.

Plessis, G.N., Griesel, L.D., Lourens, D., Gräbe, R.P., 2008. Incidence of syndesmotic injuries in all different types of ankle fractures. The South African Orthopaedic Journal 7, 28-32.

Polo Cerdá, M., 2016. Paleobiología humana de la fundación romana de Valencia. Tesis doctoral. Alicante, Universidad de Alicante. Available from: http://rua.ua.es/dspace/handle/10045/54258
Pretell Mazzini, J., Rodriguez Martin, J., 2010. Paediatric forearm and distal radius fractures: risk factors and redisplacement-role of casting indices. International Orthopaedics 34(3), 407-412.

Redfern, R., 2010. A regional examination of surgery and fracture treatment in Iron Age and Roman Britain. International Journal of Osteoarchaeology, 20, 443-471.

Redfern, R., Roberts, C., 2019. Trauma. In: Buikstra, J.E. (Ed.), Ortner's identification of pathological conditions in human skeletal remains, 211-284, third ed. Academic Press, London.

Richardson, W.F., 1979. Celsus on Medicine. Prudentia 11(2), 69-93.

Robles, D.S., Esteves, S., Martins, S., Ferreira, N., Marinheiro, J., Sousa, C., 2015. Dor persistente após entorse do tornozelo um caso clínico de sinostose do ligamento tíbio-peroneal anterior distal. Revista Portuguesa de Ortopedia e Traumatologia 23(3), 257-264.

Silva, F.C., 2015. The funerary practice of cremation at Augusta Emerita (Mérida, Spain) during High Empire: contributions from the anthropological analysis of burned human bone. In: Thompson, T. (Ed.), The Archaeology of cremation: burned human remains in funerary studies, 123-150. Oxbow, Oxford.

Silva, F.C., 2018. Mundo funerário romano sob o prisma da cremação: análise antropológica de amostras alto-imperiais da Lusitania. Tese de Doutoramento em Antropologia Biológica, Universidade de Coimbra. Available from: https://estudogeral.sib.uc.pt/handle/10316/87497.

Silva, F.C., Márquez Pérez, J., Rosa, J., Santos, A.L., 2014. Health care and survival of a child with cranial trauma at Augusta Emerita (Spain). In: Michaelides, D. (Ed.), Medicine and Healing in the Ancient Mediterranean World, 218-222. Oxbow, Oxford.

Van Heest, T.J., Lafferty, P.M. 2014. Injuries to the ankle syndesmosis. The Journal of Bone and Joint Surgery 96(7), 603-613.

Waldron, T., 2009. Paleopathology. Cambridge University Press, Cambridge.

Wasterlain, R.S., 2000. Morphé. Análise das proporções entre os membros, dimorfismo sexual e estatura de uma amostra da Colecção de esqueletos identificados do Museu Antropológico da Universidade de Coimbra. Dissertação de Mestrado em Evolução Humana. Coimbra, Departamento de Antropologia, Universidade de Coimbra. Available from: https://estudogeral. sib.uc.pt/handle/10316/9870.

Weber, BG., 1972. Die verletzungen des oberen sprunggelenkes. Verlag Hans Huber, Berne. 2nd ed.

Wells, C., 1982. The human burials. In: McWhirr, A., Viner, L., Wells, C. (Aut.), Romano-British cemeteries at Cirencester, 135-202. Cirencester Excavation Committee, Corinium Museum, Cirencester. 